Sri Winarti

\title{
STRATEGI KEPALA SEKOLAH DALAM PENINGKATAN PROFESIONALISME GURU (STUDI PADA SMP NEGERI 21 KOTA MALANG)
}

\author{
Dyah Sawitri \\ Fakultas Ekonomi dan Bisnis, PPs. Magister Manajemen Universitas Gajayana Malang \\ e-mail: dyahsawitri19@yahoo.com
}

Andarwati

Fakultas Ekonomi dan Bisnis, Universitas Brawijaya Malang e-mail: andarwati.feub@gmail.com

Sri Winaryati

SMP Negeri 23 Malang, Kota Malang

e-mail:wien_rajajowas@yahoo.com

\begin{abstract}
ABSTRAKSI
Fokus penelitian ini adalah: Peran kepala sekolah SMPN 21 Kota Malang dalam meningkatkan profesionalisme guru; Faktor-faktor yang menjadi pendukung dan kendala dalam peningkatan profesionalisme guru di SMPN 21 Kota Malang; Strategi kepala sekolah SMPN 21 Kota Malang menangani kendala dalam peningkatan profesionalisme guru. Metode penelitian ini menggunakan rancangan kualitatif dengan metode pengambilan data melalui wawancara, observasi dan dokumentasi kepada informan.

Temuan penelitian terkait dengan fokus penelitian: Kepala sekolah dalam meningkatkan pofesionalisme guru SMPN 21 Kota Malang. Pertama, dengan mengoptimalkan fungsi kepala sekolah sebagai pemimpin, pendidik, supervisor, pencipta iklim sekolah dan wirausahawan. Kedua, Faktor kendala dalam peningkatan profesionalime guru antara lain: masih adanya tenaga pendidik yang merangkap tugas, rendahnya semangat tenaga pendidik dalam meningkatkan kompetensinya, menumpuknya beban tugas yang diberikan kepada tenaga pendidik dan sarana prasarana pendukung proses kegiatan belajar mengajar yang belum memadai. Sedangkan faktor pendukung meliputi: dukungan Dinas Pendidikan Kota Malang dalam hal penciptaan sekolah unggulan, kondisi sosial dan ekonomi masyarakat sekitar sekolah dan partisipasi Komite Sekolah yang maksimal. Ketiga, kepala sekolah memberikan pembinaan kedisiplinan, memberikan penghargaan (reward), memberikan motivasi baik secara intrinsik maupun ekstrinsik, memberikan persepsi yang baik terhadap prestasi kerja para tenaga pendidik.
\end{abstract}

Kata kunci: Strategi, kepala sekolah, profesionalisme guru. 


\section{PENDAHULUAN}

Sejak tahun 2005, isu mengenai profesionalisme guru gencar dibicarakan di Indonesia. Profesionalisme guru sering dikaitkan dengan tiga faktor yang cukup penting, yaitu kompetensi guru, sertifikasi guru, dan tunjangan profesi guru. Ketiga faktor tersebut merupakan latar yang disinyalir berkaitan erat dengan kualitas pendidikan. Guru profesional yang dibuktikan dengan kompetensi yang dimilikinya akan mendorong terwujudnya proses dan produk kinerja yang dapat menunjang peningkatan kualitas pendidikan. Guru kompeten dapat dibuktikan dengan perolehan sertifikasi guru berikut tunjangan profesi yang memadai menurut ukuran Indonesia. Fakta bahwa guru telah tersertifikasi merupakan dasar asumsi yang kuat, bahwa guru telah memiliki kompetensi.

Kompetensi guru tersebut mencakup empat jenis, yaitu (1) kompetensi pedagogi (2) kompetensi profesional, (3) kompetensi sosial, dan (4) kompetensi kepribadian (UndangUndang No 20 Tahun 2005). Persoalan yang muncul kemudian, bahwa guru yang diasumsikan telah memiliki kompetensi yang hanya berlandaskan pada asumsi bahwa mereka telah tersertifikasi, tampaknya dalam jangka panjang sulit untuk dapat dipertanggungjawabkan secara akademik. Bukti tersertifikasinya para guru adalah kondisi sekarang, yang secara umum merupakan kualitas sumber daya guru sesaat setelah sertifikasi. Oleh karena sertifikasi erat kaitannya dengan proses belajar, maka sertifikasi tidak bisa diasumsikan mencerminkan kompetensi yang unggul sepanjang hayat.

Manajemen pengembangan kompetensi guru dapat diartikan sebagai usaha yang dikerjakan untuk memajukan dan meningkatkan mutu, keahlian, kemampuan, dan keterampilan guru demi kesempurnaan tugas pekerjaannya. Sehingga penelitian tentang strategi kepala sekolah dalam peningkatan profesionalisme guru penting dilakukan karena beberapa alasan: Pertama, kepala sekolah adalah sebagai pengelola instansi pendidikan tentu saja mempunyai peran yang teramat penting, karena ia sebagai designner, pengorganisasian, pelaksana, pengelola tenaga kependidikan, pengawas, pengevaluasi program pendidikan dan pengajaran di lembaga yang dipimpinnya. Kedua, secara operasional kepala sekolah memiliki standar kompetensi untuk, menyusun perencanaan strategis, mengelola tenaga kependidikan, mengelola kesiswaan, mengelola fasilitas, mengelola sistem informasi manajemen, mengelola mutu pendidikan, mengelola kelembagaan, mengelola kekompakan kerja (team work) dan pengambil keputusan. Ketiga, gurupun memepunyai peranan yang sangat penting yaitu sebagai ujung tombak pelaksanaan proses kegiatan belajar mengajar, dilapangan guru berperan sebagai transformator (orang yang memindahkan) ilmu pengetahuan, teknologi, menanamkan keilmuan, ketaqwaan dan membiasakan peserta didik berakhlakul karimah serta mandiri. Keempat, guru dalam melaksanakan tugas yaitu membantu murid/ siswa dalam proses pembelajaran masih banyak kendala diantaranya: masih adanya guru yang merangkap tugas, rendahnya guru dalam meningkatkan kompetensi, menumpuknya beban tugas, kurangnya sarana dan prasarana dalam proses pembelajaran. Oleh karena itu diperlukan sistem kerja sama yang baik antara kepala sekolah, guru, staff tata usaha dan semua pihak yang berkepentingan (stakeholder) dengan pendidikan di sekolah. 
Sri Winarti

\section{Rumusan Masalah}

Berdasarkan latar belakang yang telah diuraikan sebelumnya, maka rumusan masalah dalam penelitian ini adalah:

1. Apa sajakah Strategi yang dilakukan oleh kepala sekolah dalam meningkatkan profesionalisme guru di SMPN 21 Kota Malang?

2. Apa saja factor-faktor yang menjadi kendala dan pendukung dalam peningkatan profesionalisme guru di SMPN 21 Kota Malang?

3. Bagaimana upaya yang dilakukan kepala sekolah dalam menangani faktor kendala peningkatan profesionalisme guru di SMPN 21 Kota Malang?

\section{Tujuan Penelitian}

Sesuai dengan rumusan masalah, maka penelitian ini bertujuan untuk mendeskripsikan hal-hal sebagai berikut :

1. Untuk menggambarkan dan mengetahui peran yang dilakukan oleh kepala sekolah dalam meningkatkan profesionalisme guru di SMPN 21 Kota Malang.

2. Untuk mengetahui factor-faktor yang menjadi kendala dan pendukung dalam peningkatan profesionalisme guru di SMPN 21 Kota Malang.

3. Untuk mengetahui strategi yang dilakukan kepala sekolah dalam menangani faktor kendala peningkatan profesionalisme guru di SMPN 21 Kota Malang.

\section{LANDASAN TEORI}

\section{Manajemen Sumber Daya Manusia}

Untuk menghadapi persaingan dalam organisasi dituntut adanya kemampuan dalam mengadakan perubahan. Setiap perubahan saharusnya harus memiliki unsur keunggulan kualitas. Dalam dunia pendidikan terlebih di organisasi Perguruan tinggi, pengendalian kualitas merupakan suatu keharusan. Seperti pernyataan Pannen (1997) bahwa, pengendalian kualitas pendidikan berfungsi guna membina peraturan-peraturan pendidikan dan standar pendidikan untuk mencapai tujuan pendidikan yang sesuai dengan tujuan pembangunan bangsa. Apa sebenarnya kualitas itu?, dikatakan oleh Evan dan Dean, (2003) dalam Nursya'bani Purnama, (2006:9) kualitas adalah keseluruhan ciri-ciri dan karakteristik dari suatu produk atau layanan menyangkut kemampuan untuk memenuhi kebutuhan yang telah ditentukan dan atau bersifat laten.

Cushway (1994:13) menyatakan bahwa sumber daya manusia didefinisikan sebagai "Part of the process that helps the organizational achieve its objectives". Karena sumber daya manusia adalah potensi yang merupakan asset penting yang berfungsi sebagai modal dalam organisasi.karena itu pengembangan sumber daya manusia dalam organisasi dapat meningkatkan keahlian, ilmu pengetahuan dan sikap karyawan. Ungkapan ini telah dinyatakan oleh Lusthaus dkk. (2002:48) yang menyatakan: "Developing human resources in an organization means improving employee performance by increasing or improving their skills, knowledge and attitudes". Selain itu juga sumber daya manusia adalah merupakan potensi manusiawi sebagai penggerak orgasisasi, hal ini telah dikatakan oleh (Nawawi, 2005).

\section{Kepemimpinan Sekolah Masa Depan}

Tantangan nyata bagi pemimpin sekolah dalam dekade mendatang menurut Neil Shipman, Direktur dari Interstate School Leaders Licensure Consertium (ISLLC), adalah lebih menitik beratkan pada proses belajar mengajar dari pada sekedar menjadi seorang manajer (Hoy \& Miskel, 1987). 
Sri Winarti

The Interstate School Leaders Licensure Consortium (ISLLC) (konsorsium kewenangan pemimpin sekolah antar negara bagian) of the Council of Chief State School Officer (dalam Suyitno 2008) menjelaskan pentingnya kepemimpinan dalam proses belajar mengajar dan menjelaskan enam standar. Seorang kepala sekolah sebagai pemimpin pembelajaran dapat menaikkan tingkat keberhasilan semua siswa melalui:

a. Memberi fasilitas pengembangan, memberikan gagasan, implementasi, dan pengurusan visi pembelajaran yang dibuat bersama dan didukung masyarakat sekolah.

b. Memberi anjuran, memelihara, dan mendukung budaya sekolah dan program pengajaran yang kondusif bagi pembelajaran siswa dan pertumbuhan profesional bagi staff / guru.

c. Menjamin manajemen organisasi, pelaksaaan dan sumber-sumber dalam rangka mencapai lingkungan belajar yang aman, efektif dan efisien.

d. Melakukan kerja sama dengan keluarga, anggota masyarakat, menanggapi minat dan kebutuhan masyarakat, dan memanfaatkan sumber-sumber pada masyarakat.

e. Berperilaku secara integritas, penuh kejujuran dan beretika.

f. Memahami, menanggapi pengaruh politik, sosial dan ekonomi, dan konteks budaya. (ISLLC 1997)

\section{Profesionalisme Guru}

Sebenarnya apakah seorang guru itu harus profesional? Dalam pasal 35 ayat (1) Undang-Undang Republik Indonesia nomor 20 tahun 2003 tentang Sistem Pendidikan Nasional dinyatakan bahwa standar nasional pendidikan yang terdiri atas standar isi, standar proses, standar kompetensi lulusan, standar tenaga kependidikan, standar sarana dan prasarana, standar pengelolaan, standar pembiayaan, dan standar penilaian pendidikan harus ditingkatkan secara berencana dan berkala.

Undang-Undang Republik Indonesia nomor 14 tahun 2005 tentang Guru dan Dosen, mengisyaratkan bahwa guru adalah pendidik profesional dengan tugas utama mendidik, megajar, membimbing, mengarahkan, melatih, menilai, dan mengevaluasi peserta didik pada pendidikan anak usia dini jalur pendidikan formal, pendidikan dasar, dan pendidikan menengah. Profesional dalam pendidikan perlu dimaknai bahwa guru haruslah orang yang memiliki instink sebagai pendidik, mengerti dan memahami peserta didik. Guru harus menguasai secara mendalam minimal satu bidang keilmuan. Guru harus memiliki sikap integritas profesional. Kedudukan guru sebagai tenaga profesional sebagaimana dimaksud dalam Pasal 2 ayat (1) berfungsi untuk meningkatkan martabat dan peran guru sebagai agen pembelajaran berfungsi untuk meningkatkan mutu pendidikan nasional. Yang dimaksud dengan guru sebagai agen pembelajaran (learning agent) adalah peran guru antara lain sebagai fasilitator, motivator, pemacu, perekayasa pembelajaran, dan pemberi inspirasi belajar bagi peserta didik.

Kompetensi guru sebagaimana yang dimaksud dalam Pasal 8 Undang-Undang Republik Indonesia nomor 14 Tahun 2005 meliputi kompetensi pedagogik, kompetensi kepribadian, kompetensi sosial, dan kompetensi profesional yang diperoleh melalui pendidikan profesi. 
Sri Winarti

Secara utuh sosok kompetensi guru meliputi (a) pengenalan peserta didik secara mendalam; (b) penguasaan bidang studi baik disiplin ilmu (diciplinary content) maupun bahan ajar dalam kurikulum sekolah (pedagogical content); (c) penyelenggaraan pembelajaran yang mendidik yang meliputi perencanaan dan pelaksanaan pembelajaran, evaluasi proses dan hasil belajar, serta tindak lanjut untuk perbaikan dan pengayaan; dan (d) pengembangan kepribadian dan profesionalitas secara berkelanjutan.

Pasal 7 ayat (1) Undang-undang Republik Indonesia nomor 14 tahun 2005 menyatakan bahwa profesi guru dan profesi dosen merupakan bidang pekerjaan khusus yang dilaksanakan berdasarkan prinsip sebagai berikut:

"Memiliki bakat, minat, panggilan jiwa, dan idealisme; memiliki komitmen untuk meningkatkan mutu pendidikan, keimanan, ketakwaan, dan akhlak mulia; memiliki kualifikasi akademik dan latar belakang pendidikan sesuai dengan bidang tugas; memiliki kompetensi yang diperlukan sesuai dengan bidang tugas; memiliki tanggung jawab atas pelaksanaan tugas keprofesionalan; memperoleh penghasilan yang ditentukan sesuai dengan prestasi kerja; memiliki kesempatan untuk mengembangkan keprofesionalan secara berkelanjutan dengan belajar sepanjang hayat; memiliki jaminan perlindungan hukum dalam melaksanakan tugas keprofesionalan; dan memiliki organisasi profesi yang mempunyai kewenangan mengatur hal-hal yang berkaitan dengan tugas keprofesionalan guru". (Pasal 7 (ayat 1) UU No 14 Tahun 2005)

Profesional adalah pekerjaan atau kegiatan yang dilakukan oleh seseorang dan menjadi sumber penghasilan kehidupan yang memerlukan keahlian, kemahiran, atau kecakapan yang memenuhi standar mutu atau norma tertentu serta memerlukan pendidikan profesi. Guru sebagai tenaga profesional mengandung arti bahwa pekerjaan guru hanya dapat dilakukan oleh seseorang yang mempunyai kualifikasi akademik, kompetensi, dan sertifikat pendidik sesuai dengan persyaratan untuk setiap jenis dan jenjang pendidikan tertentu (Suyitno, 2008). Dalam melaksanakan tugas keprofesionalan, guru berkewajiban:

a. Merencanakan pembelajaran, melaksanakan proses pembelajaran yang bermutu, serta menilai dan mengevaluasi hasil pembelajaran;

b. Meningkatkan dan mengembangkan kualifikasi akademik dan kompetensi secara berkelanjutan sejalan dengan perkembangan ilmu pengetahuan, teknologi, dan seni;

c. Bertindak objektif dan tidak diskriminatif atas dasar pertimbangan jenis kelamin, agama, suku, ras, dan kondisi fisik tertentu, atau latar belakang keluarga, dan status sosial ekonomi peserta didik dalam pembelajaran;

d. Menjunjung tinggi peraturan perundang-undangan, hukum, dan kode etik guru, serta nilai-nilai agama dan etika; dan

e. Memelihara dan memupuk persatuan dan kesatuan bangsa. (Suyitno, 2008). 
Sri Winarti

\section{Kerangka Pikir}

Berdasarkan masalah, tujuan, dan kajian teori, maka kerangka pikir pada penelitian ini adalah, sebagai berikut:

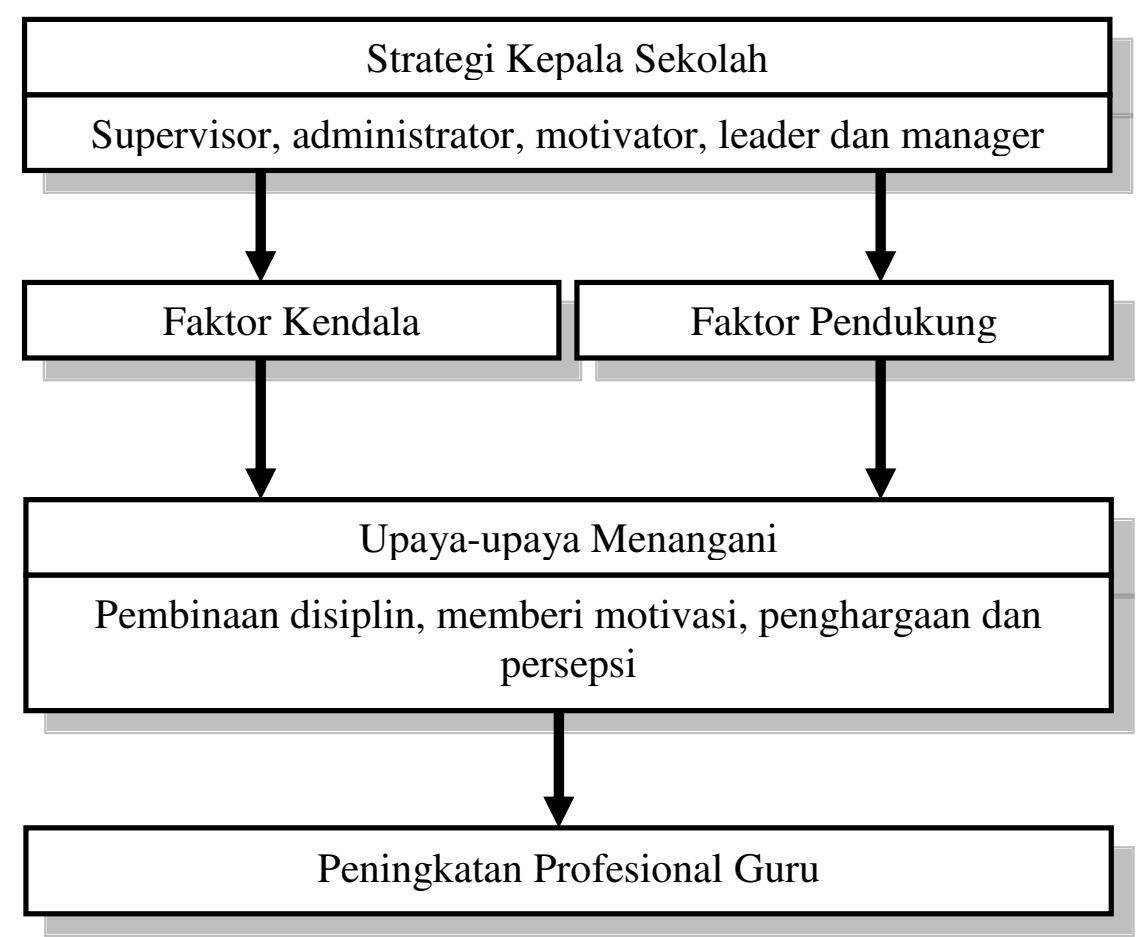

Sumber: Kementerian Dikbud ( 2012), Sergiovanni (1991), diolah peneliti, Tahun 2013

\section{Gambar 1. \\ Strategi Kepala Sekolah Dalam Peningkatan Profesionalisme Guru METODE PENELITIAN}

\section{Jenis Penelitian}

Didasarkan pada cakupan dan realitas yang ingin dikaji strategi kepala sekolah dalam upaya peningkatan profesionalisme guru yang cenderung dapat didekati secara studi kasus, maka penelitian ini menggunakan pendekatan penelitian kualitatif. Penelitian ini disesuaikan dengan permasalahan yang muncul dan tujuan penelitian yang ingin memperoleh gambaran menyeluruh tentang strategi kepala sekolah dalam upaya peningkatan profesionalisme guru. Hal ini juga ditegaskan (Suyitno 2006) bahwa metode kualitatif cocok digunakan untuk memperoleh gambaran menyeluruh mengenai suatu fenomena. Pemilihan metode kualitatif ini akan memiliki berbagai implikasi dalam penelitian yang akan dilakukan berdasarkan ketergantungan logis pada aksioma-aksioma sebagaimana yang diungkapkan oleh Lincoln dan Guba (1985).

\section{Sumber Data Penelitian}

Sumber data penelitian kualitatif sebagaimana dinyatakan Arikunto (1998) dapat berupa orang (person), tempat (place), dan simbol (paper). Sedangkan menurut Spradley (Sugiono, 2006; Faisal, 1990) menunjuk pada tiga kategori, yakni pelaku (actor), aktivitas (activity), dan tempat (place). Berdasarkan kedua pendapat di atas, maka sumber data penelitian ini terdiri dari empat kategori sebagai berikut: 
Sri Winarti

1. Sumber data berupa orang/pelaku sebagaimana telah diuraikan sebelumnya meliputi kepala sekolah, wakil kepala sekolah, guru, komite sekolah dan pihak lain terkait yang memiliki peran dalam upaya-upaya kearah optimalisasi potensi dalam pengembangan kinerja gueu di SMPN 21 Kota Malang. Penentuan sumber data pihak-pihak tersebut dilakukan secara purposive dan snowball dengan pertimbangan tertentu. Penetapan kepala sekolah, wakil kepala sekolah, komite sekolah sebagai informan dengan menggunakan teknik purposive sampling didasarkan pada pertimbangan peran mereka yang spesifik sesuai job kerjanya sehingga dipandang representatif untuk dijadikan sumber data. Pertimbangan lain, bahwa subyek cukup lama dan intensif menyatu dengan kegiatan dan menghayati secara sungguh-sungguh sebagai akibat keterlibatannya, subyek masih terlibat secara penuh/aktif pada lingkungan atau kegiatan yang menjadi perhatian peneliti, dan subyek mempunyai cukup waktu untuk diwawancarai. Berikutnya snowball sampling merupakan teknik penentuan sumber data yang semula jumlahnya sedikit lamalama menjadi besar sehingga spesifikasi sampel tidak dapat ditentukan sebelumnya. Teknik ini menurut Lincoln \& Guba (1985), memiliki karakteristik, yakni desain sampel sementara, pemilihan unit sampel yang menggelinding seperti salju, pemilihan sampel disesuaikan kebutuhan, dan dipilih sampai jenuh. Dalam penelitian ini mula-mula peneliti menentukan kepala sekolah dan salah seorang guru untuk diminta informasi mengenai upaya peningkatan profesionalisme guru, program dan kegiatan-kegiatan yang mendukung upaya optimalisasi potensi guru berikut aspek-aspek yang melingkupinya. Setelah wawancara berlangsung ternyata banyak informasi mengenai permasalahan tersebut yang dapat digali pada guru-guru lainnya, sehingga peneliti menggali informasi kepada guru lain yang dimaksud oleh guru pertama, demikian seterusnya seterusnya.

2. Sumber data berupa tempat, yakni SMPN 21 Kota Malang sebagai institusi pendidikan yang melaksanakan pengembangan kompetensi guru untuk mendukung peningkatan profesionalisme guru.

3. Sumber data berupa aktivitas, dalam hal ini merujuk pada berbagai kegiatan yang relevan dengan fokus masalah penelitian. Kegiatan tersebut dapat menghasilkan gagasan, konsep, pemikiran, maupun aktivitas dalam arti practical. Lebih spesifik sumber data dalam bentuk kegiatan ini diantaranya kegiatan rapat-rapat, kegiatan monitoring dan evaluasi kinerja, kegiatan supervisi, rapat komite sekolah, pertemuan rutin pagi (briefing) dan sebagainya. Peneliti mengamati berbagai kegiatan tersebut sambil merekam dalam bentuk catatan, gambar dan rekam suara.

4. Sumber data berupa simbol (paper) dalam penelitian ini antara lain simbol-simbol kelembagaan, atribut sekolah, atribut guru dan sebagainya yang manjadi karakteristik SMPN 21 Kota Malang. Termasuk dalam sumber ini, yakni suasana lingkungan sekolah, keberadaan sarana pendidikan, dan slogan-slogan yang mengarah pada peningkatan kompetensi guru untuk mendukung peningkatan mutu SMPN 21 Kota Malang yang terpasang di lingkungan sekolah.

\section{Metode Pengumpulan Data}

Untuk dapat mengungkap pelaksanaan pengelolaan pembiayaan pendidikan, dalam penelitian ini memerlukan beragam teknik pengumpulan data. Teknik yang akan dipergunakan untuk mengungkap permasalahan secara holistik, antara lain teknik observasi partisipatif (participant observation), yang taraf partisipasinya menyesuaikan konteks, wawancara mendalam (in-depth interview) dan dokumentasi (documentation). Sebagaimana dinyatakan (Suyitno 2007), bahwa dalam penelitian kualitatif dengan natural setting lebih banyak menggunakan ketiga teknik tersebut. 
Sri Winarti

\section{Teknik Pengamatan Partisipatif}

Teknik pengamatan partisipatif digunakan untuk menyelidiki berbagai keadaan dan kegiatan yang relevan dan memiliki makna penting bagi pencapaian tujuan penelitian ini. Teknik pengamatan partisipatif digunakan untuk mengamati implementasi pengelolaan lembaga pendidikan yang berorientasi pada pelayanan publik.

\section{Teknik Wawancara Mendalam}

Dalam teknik wawancara mendalam (indepth interview) ini, peneliti melakukan wawancara kepada kepala sekolah dan guru serta komite sekolah sebagai informen utama (key informan), dilanjutkan dengan pihak terkait yang lain secara berkelanjutan, menggunakan pertanyaan-pertanyaan non-terstruktur yang mengarah pada fokus penelitian (focused interview), namun pada latar tertentu dilakukan pendalaman (probing question). Teknik ini dimaksudkan agar subyek terteliti dapat memberikan informasi sebanyak mungkin serta dapat mengemukakan pemikiran, gagasan dan tindakannya seluas dan sebebas mungkin dalam kaitannya dengan ketrampilan manajerial kepala sekolah dalam mengawal sekolah sebagai organisasi pelayanan publik. Teknik wawancara ini dilakukan juga kepada kepala sekolah, guru, komite sekolah atau wali murid.

\section{Teknik Dokumentasi}

Teknik dokumentasi dalam penelitian ini dipergunakan untuk menggali berbagai data, peristiwa dan kebijakan yang terdokumentasikan dan sesuai dengan tujuan penelitian. Berdasarkan jenis-jenis dokumentasi tersebut secara umum dapat di bedakan menjadi dua, yakni dokumen yang sifatnya internal dan eksternal. Dokumen internal diantaranya Surat Keputusan Kepala Sekolah, dan Komite Sekolah, sumber-sumber pembiayaan sekolah, tata kerja, instruksi, tata tertib kedisiplinan, laporan rapat, keputusan pimpinan dan semacamnya yang digunakan internal sekolah sendiri. Sedangkan dokumen eksternal adalah segala macam peraturan dan perundang-undangan serta kelengkapan lain yang terkait dengan penyelenggaraan satuan pendidikan.

\section{Definisi Operasional}

Untuk lebih jelas dan terhindar dari kesalahan dalam memahami istilah-istilah yang dipergunakan dalam penelitian ini, maka dibawah ini akan dirumuskan dan dijelaskan definisi dari istilah-istilah tersebut.

1. Strategi yang dimaksud di sini adalah cara dan seni yang dipakai kepala sekolah dalam merumuskan rencana yang cermat dan menetapkan kebijakan sekolah khususnya dalam membina dan meningkatkan profesional guru dengan memanfaatkan sumber daya.

2. Kepala sekolah adalah seorang guru yang memimpin suatu sekolah. Kepala sekolah pada SMPN 21 Kota Malang berperan sebagai manajer, sebagai leader, sebagai administrator, sebagai supervisor (pengawas utama), sebagai climate maker (pembina iklim kerja), sebagai educator (pendidik) dan sebagai entrepreneur atau wiraswastawan (Dit. Dasmen. Standar Kompetensi 2002:8).

3. Profesionalisme guru adalah pekerjaan atau kegiatan yang dilakukan oleh seseorang dan menjadi sumber penghasilan kehidupan yang memerlukan keahlian, kemahiran, atau kecakapan yang memenuhi standar mutu atau norma tertentu serta memerlukan pendidikan profesi. Guru sebagai tenaga profesional mengandung arti bahwa pekerjaan guru hanya dapat dilakukan oleh seseorang yang mempunyai kualifikasi akademik, kompetensi, dan sertifikat pendidik sesuai dengan persyaratan untuk setiap jenis dan jenjang pendidikan tertentu (Suyitno, 2008). 
Sri Winarti

\section{Metode Analisis Data}

Mengacu pada pendapat Miles dan Huberman (dalam Suyitno 2007) bahwa penelitian ini dilakukan secara interaktif dan berlangsung secara terus menerus sehingga datanya sampai pada titik jenuh, lebih jelasnya ditunjukkan pada Gambar 2 sebagai berikut:

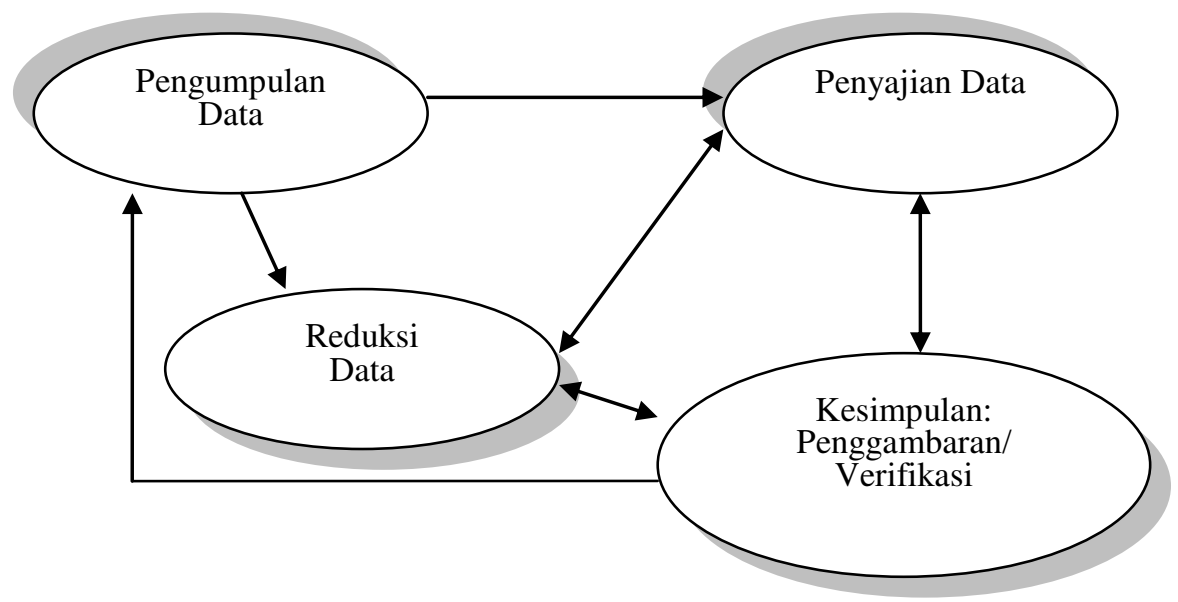

Sumber : Diadopsi dari Miles dan Huberman 1984, dioleh peneliti, Tahun 2013.

\section{Gambar 2.}

\section{Analisa Data Model Interaktif}

Setelah data tentang strategi kepala sekolah dalam peningkatan profesionalisme guru direduksi selanjutnya diorganisasikan dalam suatu bentuk tertentu yang lazim dinamakan display data (penyajian data) sehingga terlihat sosoknya secara lebih utuh. Display data dalam penelitian ini antara lain disajikan dalam bentuk uraian, bagan, hubungan antar kategori dan matriks. Tujuannya untuk memudahkan upaya pemaparan dan penegasan kesimpulan (display dan verifikasi).

Siklus analisis data prosesnya tidak sekali jadi, melainkan berinteraktif secara bolakbalik, disajikan pada Gambar 3.

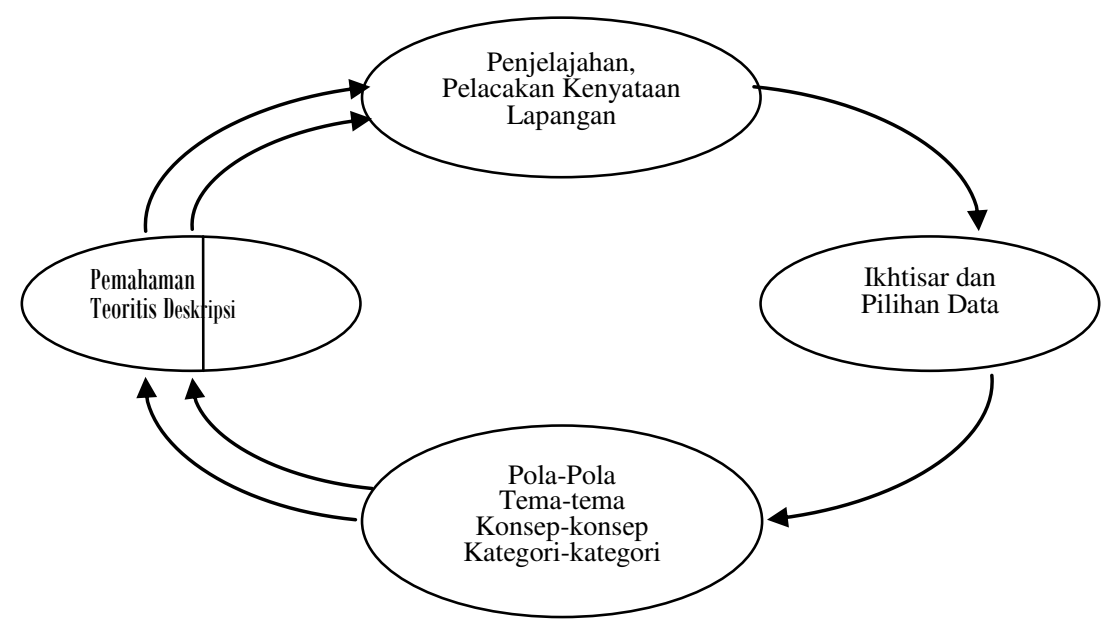

Sumber: Diolah peneliti, Tahun 2013

Gambar 3.

Siklus Analisis Data 
Sri Winarti

\section{HASIL DAN PEMBAHASAN}

\section{Hasil Penelitian}

\section{Peran Kepala Sekolah dalam Upaya Peningkatan Profesionalisme Guru SMPN 21 Malang}

Peran kepemimpinan yang diterapkan oleh Kepala SMPN 21 Kota Malang meliputi: sebagai peran sebagai pengelola, pemimpin, pendidik, administrator, penyelia, pencipta iklim kerja dan wirausahawan diharapkan mampu membawa lembaga pendidikannya kearah perkembangan yang lebih baik dan sanggup untuk berkompetisi di masa depan.

Hal yang sama juga peneliti temukan dalam dokumentasi sekolah di antaranya berbunyi sebagai berikut :

Kepala sekolah sebagai manajer, meliputi aspek-aspek di antaranya:

1. Kemampuan menyusun program, dengan indikator:
a. Memiliki proram jangka panjang (8 tahun)
b. Memiliki program jangka menengah (4 tahun)
c. Memiliki program jangka pendek ( 1 tahun)

2. Kemampuan menyusunorganisasi/personalia, dengan indikator:
a. Memiliki susunan program sekolah
b. Memiliki personalia pendukung
c. Menyusun personalia untuk kegiatan temporer

3. Kemampuan menggerakkan staf, guru,dan karyawan, dengan indikator:
a. Memiliki program pembinaan
b. Mengkoordinasikan staf yang sedang melaksanakan tugas

4. Kemampuan mengoptimalkan sumber daya sekolah.

a. Memanfaatkan sumber daya manusia secara optimal

b. Memanfaatkan sarana prasarana

c. Membuat sarana prasarana menjadi milik sekolah.

(Dok. Profil SMPN 21 Kota Malang tahun 2012/2013)

Menjalankan peran sebagai seorang manajer, Kepala SMPN 21 Kota Malang dengan selalu mengutamakan asas musyawarah melakukan perencanaan, pengorganisasian dan memimpin, serta mengendalikan program yang telah menjadi ketetapan bersama.

Sedangkan dalam menjalankan perannya sebagai leader (pemimpin), Kepala SMPN 21 Kota Malang, tampak mengayomi, mengutamakan kerjasama, saling percaya mempercayai, dan menganggap bahwa kepemimpinannya adalah sebagai suatu seni, yang dapat dilihat dari gaya, tehnik, dan kiat-kiat memimpinnya. Itulah makanya kepala sekolah sengaja menerapkan gaya kombinasi antara gaya kepemimpinan mendikte, menjual dan mendelegasikan. Hal ini untuk menyikapi sebuah fakta bahwa kondisi para tenaga pendidik di sekolah tersebut memiliki tingkat profesionalisme yang tidak sama.

Menjalankan perannya sebagai leader ini, Kepala SMPN 21 Kota Malang selalu memimpin, mengarahkan, mengayomi, mengutamakan kerja sama, saling percaya mempercayai. Dan menganggap bahwa kepemimpinannya adalah sebagai suatu seni, yang dapat dilihat dari gaya, tehnik, dan kiat-kiat memimpinnya. Sebaliknya sangat jauh dari kesan memanfaatkan kekuasaannya untuk menakut-nakuti, anak buah serba salah, menjadikan suasana kerja menjadi tegang dan menakutkan.

Peran kepemimpinan kepala sekolah sebagai seorang tenaga pendidik (educator), Kepala SMPN 21 Kota Malang menggunakan strategi yang tepat untuk meningkatkan profesionalisme para tenaga pendidik/guru, memberikan pembinaan kepada semua tenaga pendidik baik melalui rapat sekolah secara rutin maupun yang bersifat situasional, misalnya 
Sri Winarti

simulasi pembelajaran yang baik, model-model pembelajaran yang menarik, seperti team teaching dan moving class.

Demikian juga dalam menjalankan perannya sebagai administrator kepala SMPN 21 Kota Malang secara spesifik telah melakukan pengelolaan administrasi yang bersifat pencatatan, penyusunan dan pendokumenan seluruh program sekolah, meskipun kegiatankegiatan tersebut telah dibagi habis dengan tenaga kependidikan lain yang terkait. Yang meliputi pengelolaan kurikulum, pengelolaan administrasi peserta didik, pengelolaan administrasi personalia, pengelolaan administrasi sarana dan prasarana, pengeloaan administrasi kearsipan, dan pengelolaan administrasi keuangan.

Sedangkan dalam pelaksanaan perannya sebagai supervisor, kepala SMPN 21 Kota Malang telah melakukan pengawasan serta pengendalian terhadap kinerja tenaga pendidik yang merupakan kontrol agar kegiatan pendidikan di sekolah bisa terarah pada tujuan yang telah ditetapkan, sekaligus sebagai tindakan preventif untuk mencegah agar para tenaga pendidik tidak melakukan penyimpangan dalam melaksanakan pekerjaannya. Kegiatan tersebut dilakukan dengan melalui program kunjungan kelas, pembicaraan individual, diskusi kelompok dan simulasi pembelajaran, yang kemudian ditindaklanjuti dengan kegiatan pembinaan untuk memecahkan suatu masalah yang dihadapi oleh para tenaga pendidik. Meski masih belum dapat menggunakan sistem organisasi tenaga pendidik modern, yakni dengan memanfaatkan seorang supervisor secara khusus yang lebih independen, kepala sekolah telah berusaha memberikan layanan yang lebih baik kepada para tenaga pendidik. Hal ini dilakukannya sebagai pengawasan dan pengendalian untuk meningkatkan kinerja tenaga pendidik.

Pelaksanaan dalam menjalankan perannya sebagai supervisor ini, Kepala SMPN 21 Kota Malang, sangat memperhatikan prinsip-prinsip kolegial, konsultatif dan sangat demokratis serta memposisikan dirinya sebagai orang yang berada di tengah-tengah para bawahannya, tidak tampak seperti layaknya seorang diktator yang selalu mendominasi setiap kegiatan kependidikan. Hubungan kepala sekolah dengan para tenaga pendidik bukan sebagai atasan dan bawahan, namun menampilkan dirinya sebagai kolega dalam bekerja yang mengutamakan sharing dari pada memberi perintah secara langsung. 
Dyah Sawitri

Jurnal Manajemen Bisnis Indonesia

Andarwati

Vol.1, Nomor 2, Feb 2014

Sri Winarti
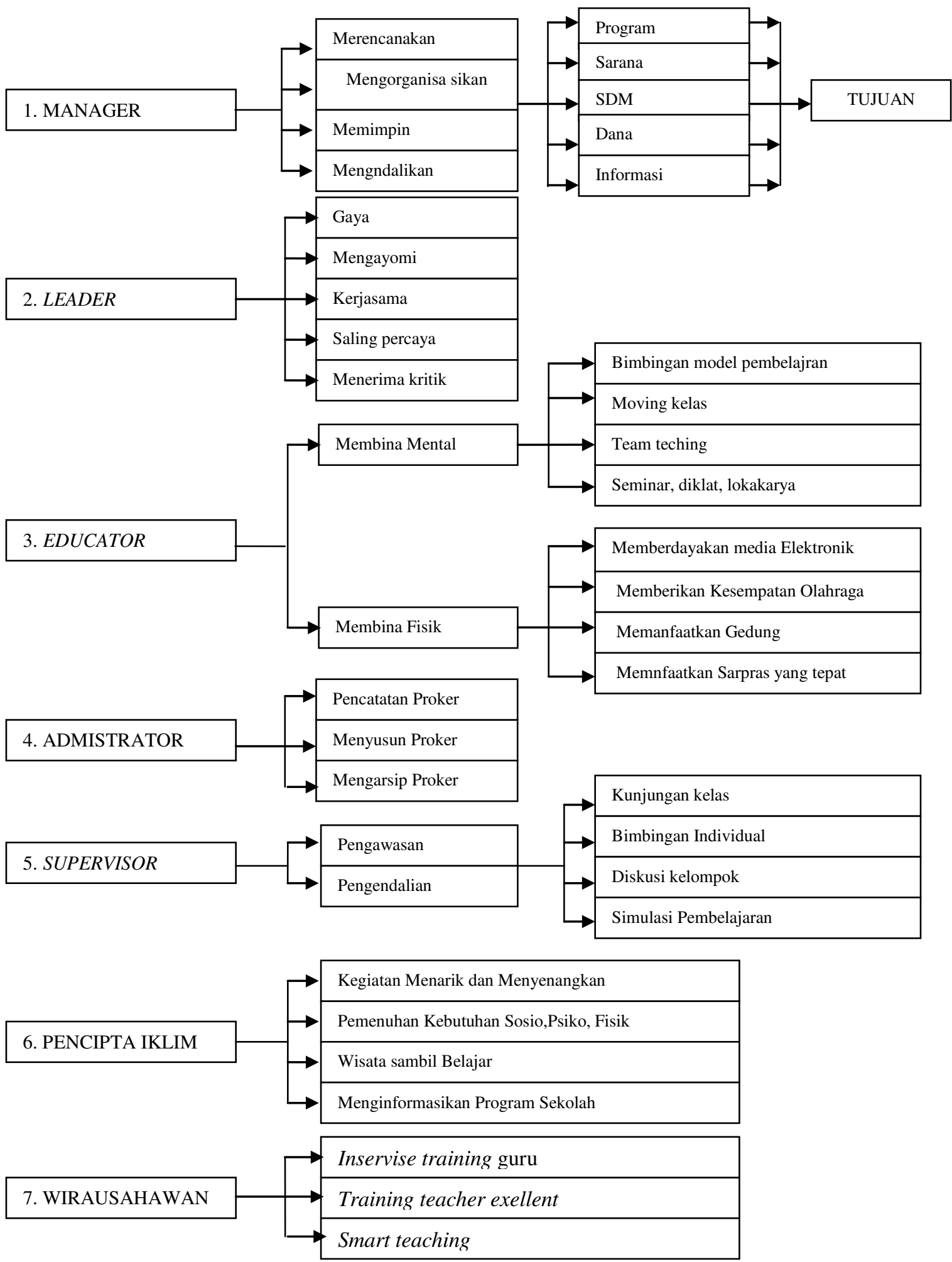

Sumber: Data Primer diolah peneliti, Tahun 2013

Gambar 4.

Peran Kepala Sekolah dalam Peningkatan Profesionalisme Guru 
Sri Winarti

Penciptaan iklim kerja yang kondusif agar para tenaga pendidik lebih termotivasi untuk menunjukkan kinerjanya secara unggul yang disertai usaha untuk meningkatkan kompetensinya, juga dilakukan oleh kepala SMPN 21 Kota Malang dengan memperhatikan prinsip-prinsip bahwa: para tenaga pendidik akan bekerja lebih giat apabila kegiatan yang dilakukannya menarik dan menyenangkan, maka kepala sekolah mengadakan wisata sambil belajar di Perpustakaan Pemerintah Daerah Kota Malang sekali waktu yang diikuti oleh semua siswa dan didampingi oleh guru-gurunya.

Kepala sekolah selalu menginformasikan semua tujuan pendidikan kepada para tenaga pendidik, agar mereka mengetahui tujuan dia bekerja serta melibat-kan para tenaga pendidik dalam penyusunan tujuan pendidikan. Dan yang lebih menarik lagi bahwa kepala sekolah menjanjikan sebuah hadiah (reward) bagi setiap tenaga pendidik yang berprestasi dalam melaksanakan tugasnya. Namun demikian juga kadang-kadang harus memberi hukuman kepada para guru yang dinilai melanggar aturan/tata tertib lembaga.

Sedangkan dalam hal pelaksanaan peran kepemimpinan kepala sekolah sebagai wirausahawan, kepala SMPN 21 Kota Malang telah melakukan pembaharuan-pembaharuan yang inovatif di sekolahnya, termasuk perubahan dalam hal-hal yang berhubungan dengan proses pembelajaran siswa beserta kompetensi para tenaga pendidik, di antaranya inservise training guru minimal sekali dalam setahun, antara lain yang pernah dilakukan kerja sama dengan Universitas Negeri Malang mengadakan "Training Teacher Exellent", dengan tema " Smart Teaching pendekatan Neo Psikologi”, dan lain-lain.

Temuan mengenai peran kepala sekolah dalam peningkatan profesionalisme guru dapat dilihat pada Gambar 4. Temuan mengenai kendala dan pendukung dalam peningkatan profesionalisme guru di SMPN 21 Kota Malang dapat dilihat pada Gambar 5, sebagai berikut:

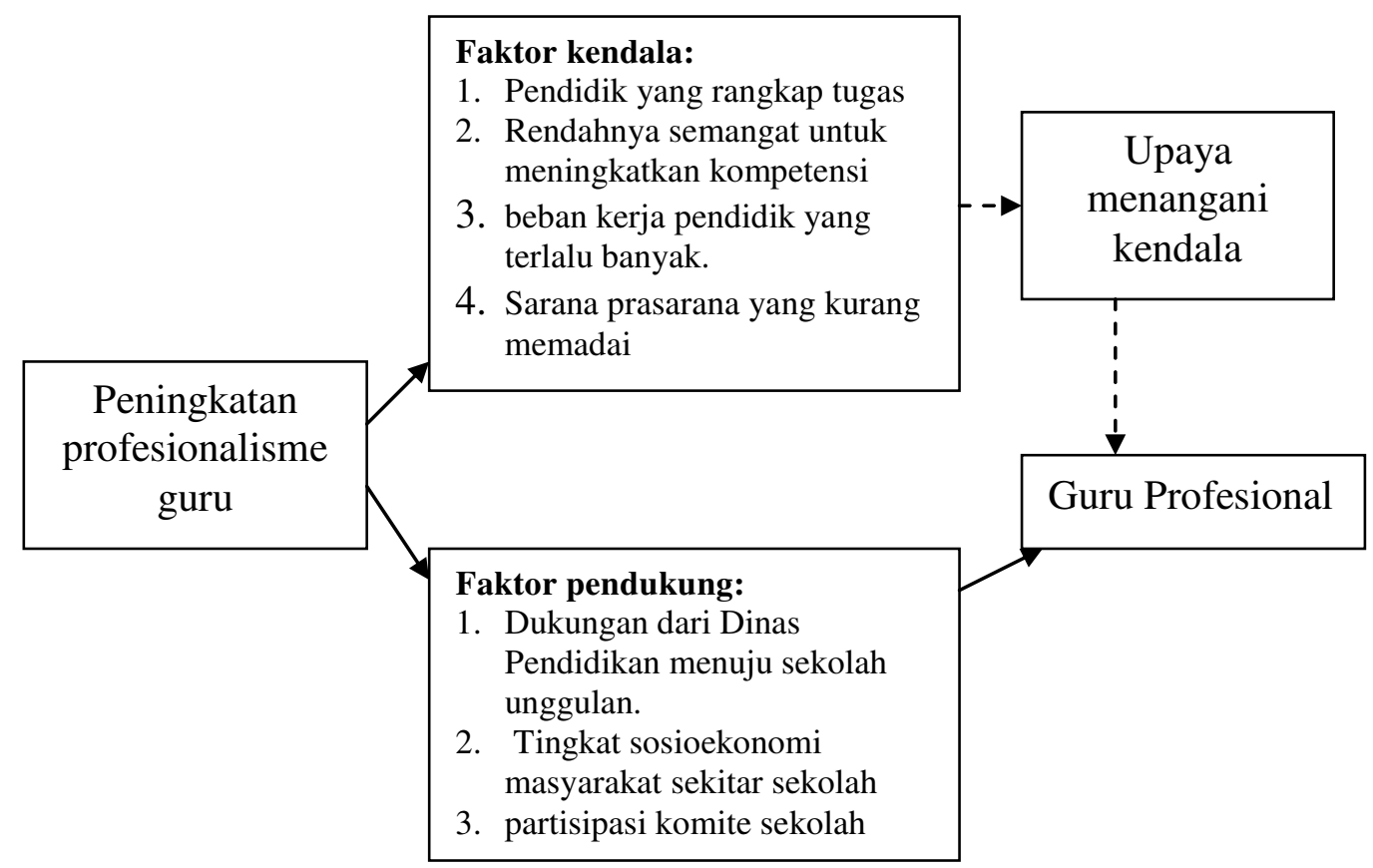

Sumber : Data Primer diolah peneliti, Tahun 2013

Gambar 5.

Faktor Kendala dan Pendukung dalam Peningkatan Profesionalisme Guru 
Sri Winarti

Temuan mengenai upaya-upaya menangani kendala-kendala dalam peningkatan profesionalisme guru dapat dilihat pada Gambar 6, sebagai berikut:

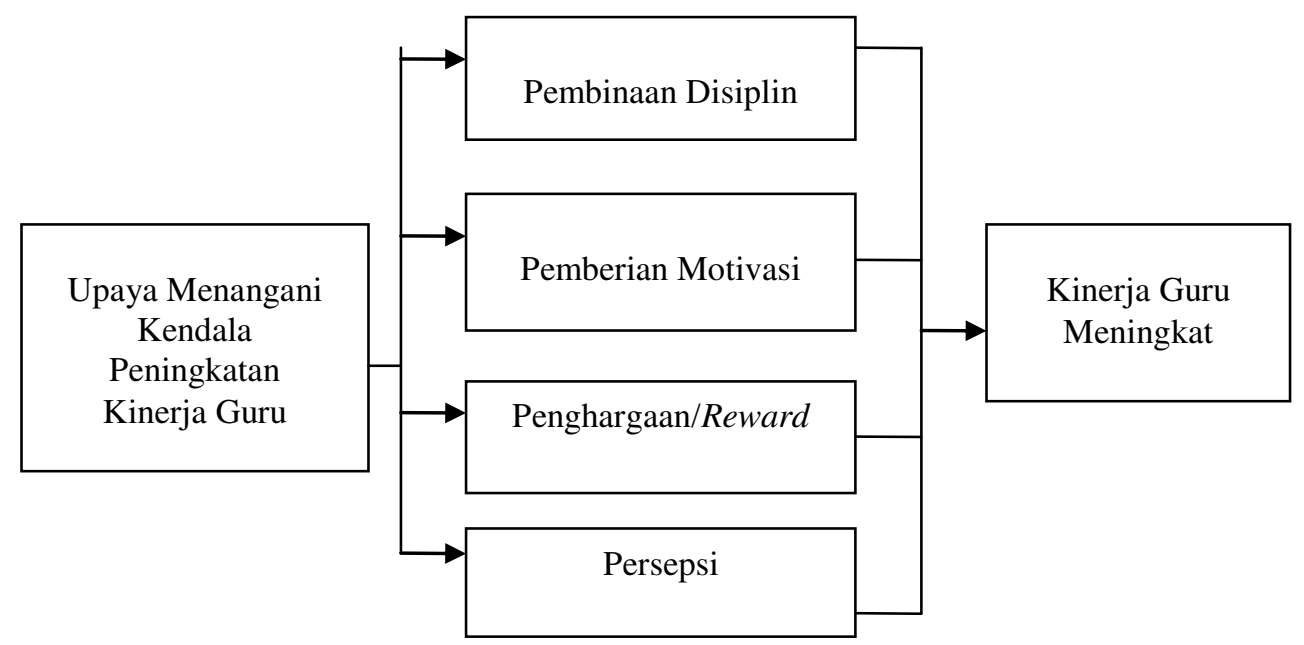

Sumber : Data Primer diolah peneliti, Tahun 2013

Gambar 6.

Upaya Menangani Faktor Kendala Dalam Peningkatan Profesionalisme Guru

\section{Pembahasan}

Dalam pembahasan ini, terdapat (tiga) buah tema yang akan dibahas secara berturutturut sebagaimana yang tercantum dalam fokus penelitian, yaitu: (1) Peran Kepala Sekolah dalam Meningkatkan Profesionalisme Guru. (2) Kendala dan Pendukung Dalam Peningkatan Profesionalisme Guru. (3) Strategi Kepala Sekolah menangani Faktor Kendala Peningkatan Profesionalisme Guru.

\section{Peran Kepala Sekolah dalam Meningkatkan Profesionalisme Guru}

Kinerja kepala sekolah SMPN 21 Kota Malang dalam pengelolaan pemberdayaan guru dapat ditegaskan bahwa dari hasil penelitian, kepala sekolah telah mampu mengelola dengan baik meskipun ada kendala, namun kendala tersebut dapat diatasi dengan kemampuan mengelola, memimpin, dan mengarahkan yang mengutamakan kerjasama serta saling percaya-mempercayai. Aktifitas proses pembelajaran yang merupakan inti dari proses pendidikan, guru sebagai salah satu pemegang utama di dalam menggerakkan kemajuan dan perkembangan dunia pendidikan. Tugas utama seseorang guru ialah mendidik, mengajar, membimbing, melatih, oleh sebab itulah tanggung jawab keberhasilan pendidikan berada di pundak guru.

Guru sebagai juru mudi dari sebuah kapal, mau kemana arah dan haluan kapal dihadapkan, bila juru mudinya pandai dan terampil, maka kapal akan berlayar selamat ditujuan, gelombang dan ombak sebesar apapun dapat dilaluinya dengan tenang dan tanggungjawab. Oleh karena itu, untuk menjadi seorang juru mudi harus melalui pendidikan dan latihan khusus serta dengan memiliki keahlian khusus. Manajemen sekolah tidak lain berarti pendayagunaan dan penggunaan sumber daya yang ada dan yang dapat diadakan secara efisien dan efektif untuk mencapai visi dan misi sekolah. Kepala sekolah bertanggung jawab atas jalannya lembaga sekolah dan kegiatannya. Kepala sekolah berada di garda 
Sri Winarti

terdepan dan dapat diukur keberhasilannya (Xaviery 2004). Hal tersebut di atas sejalan dengan hasil penelitian ini yang dirumuskan dalam proposisi sebagai berikut:

Proposisi minor I : jika kepala sekolah mengimplementasikan fungsi sebagai manager dalam organisasi pendidikan maka hal ini merupakan perwujudan dari strategi peningkatan profesionalisme guru.

Proposisi minor II : jika kepala sekolah mengimplementasikan fungsi sebagai pemimpin dalam organisasi pendidikan maka hal ini merupakan perwujudan dari strategi peningkatan profesionalisme guru.

Sedangkan dalam menjalankan perannya sebagai leader (Pemimpin), Kepala SMPN 21 Kota Malang tampak mengayomi, mengutamakan kerja sama, saling percaya mempercayai. Dan menganggap bahwa kepemimpinannya adalah sebagai suatu seni, yang dapat dilihat dari gaya, tehnik, dan kiat-kiat memimpinnya.

Menjadi guru profesional juga memerlukan pendidikan dan pelatihan serta pendidikan khusus. Manajemen berbasis sekolah merupakan suatu model manajemen yang memberikan otonomi lebih besar kepada sekolah dan mendorong pengambilan keputusan partisipatif yang melibatkan secara langsung semua warga sekolah guru, siswa, kepala sekolah, karyawan, orang tua dan masyarakat untuk meningkatkan mutu sekolah berdasarkan kebijakan pendidikan nasional (Norma Sitepu 2006).

Hal tersebut di atas sejalan dengan hasil penelitian ini yang dirumuskan dalam proposisi sebagai berikut:

Proposisi minor III : jika kepala sekolah mengimplementasikan fungsi sebagai edukator baik mental maupun fisik dalam organisasi pendidikan maka hal ini merupakan perwujudan dari strategi peningkatan profesionalisme guru.

Proposisi minor IV : jika kepala sekolah mengimplementasikan fungsi sebagai administrator dalam organisasi pendidikan maka hal ini merupakan perwujudan dari strategi peningkatan profesionalisme guru.

Proposisi minor $V$ : jika kepala sekolah mengimplementasikan fungsi sebagai supervisor dalam organisasi pendidikan maka hal ini merupakan perwujudan dari strategi peningkatan profesionalisme guru.

Proposisi minor VI : jika kepala sekolah mengimplementasikan fungsi sebagai pencipta iklim dalam organisasi pendidikan maka hal ini merupakan perwujudan dari strategi peningkatan profesionalisme guru.

Perubahan peran guru yang tadinya sebagai penyampai pengetahuan dan pengalihan pengetahuan dan pengalih keterampilan, serta merupakan satu-satunya sumber belajar, berubah peran menjadi pembimbing, pembina, pengajar, dan pelatih. Dalam kegiatan pembelajaran, guru akan bertindak sebagai fasilisator yang bersikap akrab dengan penuh tanggung jawab, serta memperlakukan peserta didik sebagai mitra dalam menggali dan mengolah informasi menuju tujuan belajar mengajar yang telah direncanakan.

\section{Faktor-Faktor Kendala dan Pendukung Dalam Peningkatan Profesionalisme Guru}

Yang dimaksud dengan profesionalisme disini adalah kemampuan dan keterampilan guru dalam merencanakan, melaksanakan pengajaran dan keterampilan, merencanakan dan melaksanakan evaluasi hasil belajar siswa.

Beberapa kendala dalam melaksanakan peningkatan professional guru, adalah dari factor internal yang menjadi sangat penting dan utama. Hal ini seperti yang ditunjukkan dalam proposisi sebagai berikut: 
Sri Winarti

Proposisi minor I : jika dalam organisasi pendidikan terdapat pendidik yang rangkap tugas, rendahnya semangat untuk meningkatkan kompetensi, beban kerja pendidik yang terlalu banyak, sarana prasarana yang kurang memadai maka upaya peningkatan profesionalisme guru akan terhambat.

Tugas pemerintah (pusat dan daerah) memberikan fasilitas dan bantuan kepada sekolah. Hal ini senada dengan proposisi sebagai berikut:

Proposisi minor II : Jika dalam organisasi pendidikan terdapat dukungan dari Dinas Pendidikan menuju sekolah unggulan, tingkat sosioekonomi masyarakat sekitar sekolah yang tinggi dan partisipasi komite sekolah maka akan mendukung upaya peningkatan profesionalisme guru.

\section{Strategi Kepala Sekolah Menangani Kendala Dalam upaya Peningkatan Profesionalisme Guru}

Sekarang ini, guru dihadapkan pada perubahan paradigma persaingan dari sebelumnya lebih bersifat physical asset menuju paradigma knowledge based competition. Perubahan paradigma tersebut menuntut efesiensi dan efektivitas penggunaan sumber daya guru, karena guru merupakan agen perubahan dan agen pembaharuan, sehingga mereka mampu bersaing dan memiliki keunggulan kompetitif. Pemantapan sumber daya guru sebagai intellectual capital harus diikuti dengan pengembangan dan pembaharauan terhadap kemampuan dan keahlian yang dimilikinya, sehingga mereka mampu dan peka terhadap arah perubahan yang terjadi. Strategi pemberdayaan merupakan salah satu cara pengembangan guru melalui employee involvement. Analog dengan pikiran (Wahibur Rokhman 2003), dapat dikonsepsikan bahwa pemberdayaan merupakan upaya kepala sekolah untuk memberikan wewenang dan tanggung jawab yang proporasional, menciptakan kondisi saling percaya, dan pelibatan guru dalam menyelesaikan tugas dan pengambilan keputusan.

Kedisiplinan juga menjadi unsur penting bagi seorang guru. Kedisiplinan ini memang menjadi kelemahan bangsa Indonesia, yang perlu diberantas sejak bangku sekolah dasar. Untuk itu hanya mungkin bila guru hidup dalam kedisiplinan sehingga anak didik dapat meneladaninya. Kedisiplinan adalah salah satu faktor yang penting dalam suatu organisasi. Dikatakan sebagai faktor yang penting karena disiplin akan mempengaruhi kinerja pegawai dalam organisasi. Semakin tinggi disiplin pegawai, semakin tinggi prestasi kerja yang dapat dicapai. Disiplin adalah merupakan cerminan besarnya tanggungjawab seseorang dalam melakukan tugas - tugas yang diberikan kepadanya yang mendorong gairah dan semangat kerja seseorang. Pada umumnya disiplin yang baik apabila pegawai datang ke kantor ataupun perusahaan dengan teratur dan tepat waktu. Mereka berpakaian serba baik pada tempat bekerjanya. Mereka menggunakan bahan-bahan dan perlengkapan dengan hati-hati. Mereka menghasilkan jumlah dan kualitas pekerjaan yang memuaskan dan mengikuti cara kerja yang ditentukan oleh perusahaan dan menyelesaikan dengan sangat baik (Hasibuan, 2000).

Dari hasil penelitian di lapangan sering terlihat beberapa guru tidak disiplin waktu, seenaknya bolos, tidak disiplin dalam koreksi pekerjaan siswa sehingga siswa tidak mendapat masukan dari pekerjaan mereka. Ketidakdisiplinan guru tersebut membuat siswa ikut-ikutan suka bolos dan tidak tepat mengumpulkan perkerjaan rumah. Yang perlu diperhatikan di sini adalah, meski guru sangat disiplin, ia harus tetap membangun komunikasi dan relasi baik dengan siswa. Kepala sekolah sebagai pimpinan sekolah mengupayakan dengan memberikan pembinaan kedisiplinan terhadap para tenaga pendidik yang meliputi perihal pengembangan pola perilaku tenaga pendidik, peningkatan standar perilaku tenaga pendidik serta menggunakan pelaksanaan aturan sebagai alat. Hal ini sejalan dengan temuan dalam penelitian ini dalam bentuk proposisi sebagai berikut: 
Sri Winarti

Proposisimayor : Jika kepala sekolah berusaha untuk menumbuhkan disiplin, memberikan penghargaan sesuai dengan prestasi, memotivasi dan memberikan persepsi yang baik kepada guru maka akan mengurangi hambatan dalam upaya peningkatan profesionalisme guru.

Manajemen peningkatan kompetensi guru bermuara pada pertumbuhan manusiawi dan profesionalisme guru (Mantja, 2002). Dalam hal ini, hubungan antara kepala sekolah dan guru bersifat proaktif mengupayakan perbaikan, pengembangan, peningkatan keefektifan dan didasarkan atas kekuatan persepsi, bakat/potensi, dan minat individu. Artinya, kepala sekolah hendaknya memiliki kepedulian terhadap kebutuhan manusiawi dan profesionalisasi guru dalam tiga perspektif. Pertama, keterlibatan guru dengan segala keunikan kepribadiannya, bakatnya, mengupayakan promosi yang wajar berdasarkan kemampuan kerja guru. Kedua, kepedulian kepala sekolah terhadap pengembangan guru. Ketiga, program peningkatan profesionalisme guru dilakukan secara kolaboratif antara kepala sekolah dan guru dalam rangka meningkatkan keefektifan sekolah. Keempat, perspektif tersebut dalam proses manajemen bersifat interdependensi dinamis.

Kepala sekolah memiliki peran strategis dalam proses pemberdayaan guru sebagai agen perubahan. Dalam hal ini, kepala sekolah dituntut memiliki kesadaran yang tinggi dalam mendistribusi wewenang dan tanggung jawab secara proporsional. Cara ini, di satu sisi merupakan proses kaderisasi, di sisi lain adalah untuk mengakomodasi proses peningkatan kompetensi guru secara berkelanjutan. Untuk menjamin keberhasilan proses pemberdayaan guru, dapat digunakan model pemberdayaan Khan (dalam Wahibur Rokhman, 2003) dengan beberpa paradigma, diantaranya paradigma desire, trust, confident, credibility, accountability, communication.

Paradigma desire merupakan upaya kepala sekolah untuk (a) memberi kesempatan kepada guru untuk mengidentifikasi permasalahan yang sedang berkembang, (b) memperkecil directive personality dan memperluas keterlibatan guru, (c) mendorong terciptanya perspektif baru dan memikirkan kembali strategi untuk meningkatkan kinerja, dan (d) menggambarkan keahlian team dan melatih guru untuk melakukan self-control.

Paradigma trust mencakup upaya kepala sekolah untuk (a) memberi kesempatan kepada guru untuk berpartisipasi dalam pembuatan kebijakan, (b) menyediakan waktu dan sumber daya pendukung yang mencukupi bagi upaya guru untuk meningkatkan kinerja, (c) menyediakan pelatihan yang mencukupi bagi kebutuhan peningkatan kinerja guru, (d) menghargai perbedaan pandangan dan mengakui kesuksesan yang diraih oleh guru, dan (e) menyediakan akses informasi yang memadai bagi upaya guru untuk meningkatkan kinerja.

Paradigma Confident merupakan upaya kepala sekolah untuk (a) mendelegasikan tugas-tugas yang dianggap penting kepada guru, (b) menggali dan mengakomodasi gagasan dan saran guru, (c) memperluas tugas dan membangun jaringan dengan sekolah dan instansi lain, dan (d) menyediakan jadwal job instruction dan mendorong munculnya win-win solution.

Beberapa upaya kepala sekolah terkait dengan paradigma credibility, adalah (a) memandang guru sebagai partner strategis, (b) menawarkan peningkat standar tinggi di semua aspek kinerja guru, (c) mensosialisasikan inisiatif guru sebagai individu kepada guru lain untuk melakukan perubahan secara partisipatif, dan (d) menggagas win-win solution dalam mengatasi perbedaan pandangan dalam penentuan tujuan dan penetapan prioritas.

Paradigma accountability merupakan upaya kepala sekolah untuk (a) menggunakan jalur training dalam mengevaluasi kinerja guru, (b) memberikan tugas yang terdefinisikan secara jelas dan terukur, (c) melibatkan guru dalam penentuan standar dan ukuran kinerja, (d) 
Sri Winarti

memberikan bantuan dan saran kepada guru dalam menyelesaikan beban kerjanya, dan (e) menyediakan periode dan waktu pemberian feedback.

Paradigma communication adalah upaya kepala sekolah untuk (a) menetapkan kebijakan open door communication, (b) menyediakan waktu untuk memperoleh informasi dan mendiskusikan permasalah secara terbuka, dan (c) menciptakan kesempatan untuk crosstraining.

\section{SIMPULAN}

1. Peran Kepala Sekolah dalam Meningkatkan Profesionalisme Guru SMPN 21 Kota Malang

a. Kepala sekolah selalu mengutamakan asas musyawarah dalam menyusun perencanaan, pengorganisasian dan kepemimpinan, serta dalam mengendalikan program yang telah menjadi ketetapan bersama.

b. Dalam hal menjalankan perannya sebagai leader, kepala sekolah selalu memimpin, mengarahkan, mengayomi, mengutamakan kerja sama, saling percaya mempercayai dan memberdayakan tenaga pendidik melalui kerja sama, dan mendorong keterlibatan seluruh tenaga pendidik dalam berbagai kegiatan yang menunjang program sekolah.

c. Dalam menjalankan perannya sebagai leader (pemimpin) ini, kepala sekolah menggunakan gaya kombinasi antara gaya kepemimpinan mendikte, menjual dan mendelegasikan.

d. Dalam menjalankan perannya sebagai seorang tenaga pendidik (educator), kepala sekolah menggunakan strategi yang tepat untuk meningkatkan profesionalisme para guru, memberikan bimbingan baik melalui rapat sekolah secara rutin maupun yang bersifat situasional.

e. Dalam menjalankan perannya sebagai supervisor, kepala sekolah telah melakukan pengawasan serta pengendalian terhadap kinerja guru yang merupakan kontrol agar kegiatan pendidikan di sekolah bisa terarah pada tujuan yang telah ditetapkan, memperhatikan prinsip-prinsip kolegial, konsultatif dan sangat demokratis serta memposisikan dirinya sebagai orang yang berada di tengah-tengah para bawahannya.

f. Dalam menjalankan perannya sebagai menciptakan iklim kerja yang kondusif agar para guru lebih termotivasi untuk menunjukkan kinerjanya secara unggul yang disertai usaha untuk meningkatkan kompetensinya, dengan selalu menginformasikan semua tujuan pendidikan kepada para guru.

g. Dalam menjalankan perannya sebagai wirausahawan kepala sekolah melakukan pembaharuan-pembaharuan yang inovatif di sekolahnya, termasuk perubahan dalam hal-hal yang berhubungan dengan proses pembelajaran siswa beserta kompetensi para guru.

\section{Faktor-Faktor Kendala dan Pendukung dalam Peningkatan Profesionalisme Guru} di SMPN 21 Kota Malang

\section{Faktor Kendala}

Faktor Kendala dalam upaya peningkatan profesionalisme guru di SMPN 21 Kota Malang meliputi:

a. Masih adanya tenaga pendidik yang merangkap tugas di lembaga lain yang hal ini dinilai dapat mengganggu konsentrasi dalam bekerja.

b. Rendahnya semangat tenaga pendidik dalam meningkatkan kompetensinya juga dapat berpengaruh pada kinerjanya. 
Sri Winarti

c. Menumpuknya beban tugas yang diberikan kepada tenaga pendidik dapat menimbulkan rasa jenuh dalam tugasnya yang berakibat menurunnya semangat dan gairah bekerja secara maksimal.

d. Sarana prasarana pendukung proses kegiatan belajar mengajar yang belum memadai.

\section{Faktor Pendukung}

Sedangkan faktor pendukung dalam upaya peningkatan profesionalisme guru di SMPN 21 Kota Malang meliputi:

a. Dukungan Dinas Pendidikan Kota Malang dalam hal penciptaan sekolah unggulan.

b. Kondisi sosial dan ekonomi masyarakat sekitar sekolah yang memiliki tingkat pendidikan dan pengetahuan akan memberikan kontrol baik secara langsung maupun tidak langsung terhadap penyelenggaraan sekolah.

c. Partisipasi Komite Sekolah yang maksimal baik dalam pemberian ide/gagasan, koreksi serta terlibat dalam perumusan-perumusan kebijakan sekolah.

3. Strategi Kepala Sekolah dalam Menangani Kendala-Kendala dalam Peningkatkan Profesionalisme Guru SMPN 21 Kota Malang

Upaya-upaya yang dilakukan oleh kepala SMPN 21 Kota Malang, untuk menangani kendala-kendala dalam peningkatan profesionalisme guru antara lain:

a. Berusaha untuk menumbuhkan disiplin guru sebagai tenaga pendidik untuk mengembangkan pola perilaku, meningkatkan standar perilakunya.

b. Pemberian motivasi, baik motivasi yang bersifat intrinsik dan ekstrinsik.

c. Pemberian penghargaan (reward). Dalam hal ini kepala sekolah secara terbuka menawarkan sebuah penghargaan (reward), yang dikhususkan bagi para tenaga pendidik yang berhasil meraih prestasi yang ada hubungannya dengan kegiatan akademik dilembaganya.

d. Persepsi, dalam upaya untuk meningkatkan kinerja guru, juga dilakukan oleh kepala sekolah dengan memberikan perhatian penuh terhadap prestasi kerja para tenaga pendidik dengan menggunakan panca indera langsung. Hal ini dilakukan oleh kepala sekolah dengan didasari oleh asumsi bahwa dengan pemberian persepsi yang baik diyakini akan dapat menimbulkan iklim kerja yang lebih kondusif serta akan mampu meningkatkan produktivitas kerja.

\section{KETERBATASAN PENELITIAN}

Keterbatasan penelitian ini pada metode pengambilan sampelnya, karena tidak semua guru menjadi sampel sehingga belum bisa digunakan untuk menarik kesimpulan secara general. Untuk memperjelas hasil penelitian ini, diharapkan ada peneliti lebih lanjut untuk hasil yg bisa digeneralisasikan dalam strategi yang terkait dengan profesional guru.

\section{SARAN BAGI PENELITI BERIKUTNYA}

Dari proses pengolahan data dapat diketahui bahwa hasil penelitian yang terkait dengan strategi kepala sekolah dalam peningkatan profesionalisme guru, ditemukan beberapa faktor penghambat dalam upaya tersebut . Sehingga perlu dikaji lebih lanjut temuan pada penelitian-penelitian lain yang sejenis sehingga bisa didapatkan penyempurnaan-penyempurnaan temuan dan akan dapat dijadikan referensi untuk penelitian berikutnya. 
Dyah Sawitri

Andarwati

Sri Winarti
Jurnal Manajemen Bisnis Indonesia

Vol.1, Nomor 2, Feb 2014

\section{DAFTAR REFERENSI}

Arikunto, S. 1998. Prosedur Penelitian Suatu Pendekatan Praktek. PT. Rineka Cipta

Bogdan, R. C \& S. J Taylor. 1993. Introduction to Qualitative Research Method; A Phenomenological Approach to the Social Science, Alih Bahasa Arief F, John Wiley and Sons-Usaha Nasional, New York- Surabaya.

Bogdan, R. C., \& Biklen,.S.K. 1998. Qualitative Research In Education: An Introduction to Theory and Methods. Boston : Allyn and Bacon.

Burhanuddin. 1994. Analisis Administrasi, Mmanajemen dan Kepemimpinan Pendidikan. Jakarta: Penerbit Bumi Aksara.

Cipta. Jakarta.

Cushway, Barry. 1994. Human resource management Fast-track MBA series Kogan Page: Pennsylvania State University

Danim, Sudarwan. 2002. Inovasi pendidikan: Dalam Upaya Peningkatan Profesionalisme Tenaga Kependidikan. Bandung: Pustaka Setia.

Depdiknas. 2004. Pola Pembinaan Sistem Pendidikan Tenaga Kependidikan PGSD. Jakarta: Depdiknas.

Depdiknas. 2005. Undang-Undang RI Nomor 14 Tentang Guru dan Dosen.Jakarta: Depdiknas.

Dimyati, H M. 2004. Paradigma dan Prinsip-Prinsip Penelitian Kualitatif. Makalah Lokakarya Metodologi Peneliitian Kualitatif. Lembaga Penelitian UM Malang

Echols, John M. dan Hasan Shadily. 1997. Kamus Inggris-Indonesia: An English-Indonesian Dictionary. Jakarta: Penerbit PT. Gramedia.

Faisal, Snapiah. 1990. Metode Penelitian Pendidikan. Surabaya: PT. UsahaUsaha Nasional.

Fathan, A. 2005. Konsep dan Metode Penelitian Kualitatif beserta contoh proposal penelitiannya. Malang: PPs-UM Prodi Pendidikan Geografi Tidak dipublikasikan..

Fattah, N. 2003. Konsep Manajemen Berbasis Sekolah MBS. dan Dewan Sekolah. Bandung : Pustaka Bani Quraisy.

Fullan. 2001. The Meaning of Educational Change. New York: Teachers College Press.

Hasballah. 1999. Dasar-Dasar Ilmu Pendidikan. Jakarta: PT. RajaGrafindo Persada.

Hasibuan, Malayu SP. 2001. Manajemen: Dasar, Pengertian, dan Masalah. Jakarta: Bumi Aksara.

Hoy \& Miskel, 1987. Education Administration.: Theory, Research and Practice. New York: Random Hause. 
Sri Winarti

King, Patricia. 1993. Performance Planning and Appraisal. New York: McGraw-Hill Book Company.

Lamatenggo. 2001. "Kinerja Guru: Korelasi antara Persepsi Guru terhadap Perilaku Kepemimpinan Kepala Sekolah, Motivasi Kerja dan Kinerja Guru SD di Gorontalo”. Tesis. Jakarta: Universitas Negeri Jakarta.

Lincoln, Y. S \& Guba E. G, 1985. Naturalistic Inquiry. Beverly Hill: SAGE Publication. Inc.

Luthans, F. 2002. Positive organizational behavior: Developing and managing psychological strengths. Academy of Management Executive, 16(1): 57-72

Malhotra, N.K. 1996. Marketing Research An Applied Orientation. Prentice Hall International. London

Mantja, W. 2007. Profesionalisasi Tenaga Kependidikan: Manajemen Pendidikan dan Supervisi Pengajaran. Malang: Elang Mas.

Moedjiarto. 2001. Sekolah Unggul: Metodologi untuk Meningkatkan Mutu Pendidikan. Jakarta: Duta Graha Pustaka.

Moleong, L. J. 1994. Metodologi Penelitian Kualitatif. Cetakan kedua. Bandung: Remaja Rosdakarya.

Mudhoffir, 1993. Prinsip-prinsip Pengelolaan Pusat Sumber Belajar. Bandung: Remaja Karya.

Mulyana, D. 2004. Metodologi Penelitian Kualitatif: Paradigma Baru Ilmu Komunikasi dan Ilmu Sosial lainnya. Bandung: Remaja Rosda Karya.

Mulyasa. 2002. Manajemen Berbasis Sekolah: Konsep, Strategi dan Implementasi. Bandung: PT. RajaGrafindo Persada.

Nunung Chomzanah dan Atingtedjasutisna. 1994. Dasar-Dasar Manajemen. Bandung : Penerbit Armico.

Pannen dan Purwanto. 1997. Punulisan Bahan Ajar. Jakarta: Depdikbud

Purnama, Nursya'bani. 2006. Manajemen Kualitas: Perspektif Global. Yogyakarta: Ekonisia.

Purwanto, Ngalim. 1998. Administrasi dan Supervisi Pendidikan. Bandung: Penerbit PT. Remaja Rosdakarya.

Republik Indonesia. 2006. Undang-Undang Republik Indonesia No. 14 Tahun 2005 Tentang Guru dan Dosen serta UU No. 20 Tahun 2003 Tentang SISDIKNAS. Bandung: Penerbit Citra Umbara.

Robbins, Stephen R. 2003. Perilaku Organisas Jilid I. Terjemahan Tim Indeks. Jakarta: PT. Ineks Kelompok Gramedia.

Rosyada, Dede. 2004. Paradigma Pendidikan Demokratis: Sebuah Model Pelibatan Masyarakat dalam Penyelenggaraan Pendidikan. Jakarta: Kencana.

Sahertian. 2000. Konsep Dasar dan Teknik Supervisi Pendidikan: Dalam Rangka Pengembangan Sumber Daya Manusia. Jakarta: Rineka Cipta.

Sawitri, Dyah. 2008. Program Pelatihan dan Pengembangan manajemen Sumber daya Manusia: Perspektif Teori Strategik. Jurnal Sosio-Religia Vol 7 No 4. Agustus 2008. 
Sri Winarti

Sergiovanni, T. J. 1991. The Principalship: A Reflective Practice Perspective. Massachusetts: Alyn and Bacon.

Siagian, Sondang P. 1992. Fungsi-Fungsi Manajerial. Jakarta: Penerbit Bumi Aksara.

Siagian, Sondang P. 1996. Manajemen Sumber Daya Manusia. Jakarta: Penerbit Bumi Aksara.

Silahahi, Ulbert. 2002. Studi tentang Ilmu Administrasi: Konsep, Teori, dan Dimensi. Bandung: Sinar Baru Algensindo.

Sitepu, Bintang P. 2012. Penulisan Buku Teks Pelajaran. Bandung: PT Remaja Rosdakarya.

Steers, Richard M. 1985. Efektivitas Organisasi, Erlangga, Jakarta

Strengthening Educational Leadership; The ISLLC Standards. Murphy, Joseph; Shipman, Neil; Pearlman, Mari Streamlined Seminar, v16 n1 pl-4 Sep 1997

Sugiyono. 2007. Metode Penelitian Adminitrasi. Edisi Kelimabelas. Bandung: CV. Alfabeta.

Supriadi, D. 2000. Reformasi Pendidikan Dalam Konteks Otonomi Daerah.Yogyakarta: Adicita.

Sutopo 1999. Administrasi, Manajemen dan Organisasi. Jakarta: Lembaga Administrasi Negara.

Suyitno dan Tanzeh, 2007. Dasar-Dasar Penelitian, Surabaya. Elkhaf

Suyitno, 2008. Kepemimpinan Pendidikan dalam Orientasi Efektivitas Organisasi, Surabaya, Elkhaf.

Suyitno, 2011. Model Pembinaan dan Supervisi Pendidikan. Malang, Sinar Akademika Malang.

Tim Penyusun. 2010. Pedoman Format Penulisan Tesis, Program Pascasarjana Univ. Gajayana Malang.

Undang-Undang Republik Indonesia Nomor 20 Tahun 2003 Tentang Sistem Pendidikan Nasional

Wahibur, Rokhman, J. 2003. Pemberdayaan dan komitmen: Upaya mencapai kesuksesan organisasi dalam menghadapi persaingan global. Dalam Usmara, A Ed..: Paradigma baru manajemen sumber daya manusia. 121-133. Yogyakarta: Amara Book.

Wahjosumidjo. 1999. Kepemimpinan Kepala Sekolah: Tinjauan Teoritik dan Permasalahannya. Jakarta: PT. Raja Grafindo Persada

Xaviery. 2004. Benarkah Wajah Sekolah Ada Pada Kepala Sekolah. Diambil dari www.diknas.go.id. 